\title{
Three new genera of jumping spider from Brazil (Araneae, Salticidae)
}

\author{
Gustavo R. S. Ruiz ${ }^{1,2} \&$ Antonio D. Brescovit ${ }^{1}$ \\ 1 Laboratório de Artrópodes, Instituto Butantan. Avenida Vital Brazil 1500, 05503-900 São Paulo, São Paulo, Brasil. \\ 2 Departamento de Zoologia, Instituto de Biociências, Universidade de São Paulo. Rua do Matão, Travessa 14, 101, \\ 05508-080 São Paulo, São Paulo, Brasil. E-mail: gustavoruiz86@hotmail.com, adbresc@terra.com.br
}

\begin{abstract}
Nosferattus gen. nov., Capeta gen. nov. and Amatorculus gen. nov. are proposed from North and Northeastern Brazil. Due to the absence of teeth on the retromargin of the chelicerae, these genera are included within the Sitticinae, and are probably related to the genus Aillutticus Galiano, 1987, with which they share a high, broad carapace, rounded laterally behind the posterior lateral eyes, and the cephalic region slightly convex. Nosferattus is proposed to include five species: the type species Nosferattus discus sp. nov. and Nosferattus ciliatus sp. nov. from Maranhão, Nosferattus aegis sp. nov. from Tocantins, Nosferattus occultus sp. nov. from Maranhão and Ceará, and Nosferattus palmatus sp. nov. from Sergipe. Capeta and Amatorculus are both monotypic and are proposed to include Capeta tridens sp. nov., from Bahia, and Amatorculus stygius sp. nov., from Distrito Federal and São Paulo, respectively. KEY WORDS. Amycoida, neotropical, Sitticinae, systematics, taxonomy.
\end{abstract}

RESUMO. Três gêneros novos de aranha papa-mosca do Brasil (Araneae, Salticidae). Nosferattus gen. nov., Capeta gen. nov. e Amatorculus gen. nov. são propostos para o norte e nordeste do Brasil. Devido à ausência de dentes na retromargem das quelíceras, estes gêneros são incluídos entre os Sitticinae, e provavelmente estão relacionados ao gênero Aillutticus Galiano, 1987, com o qual compartilham uma carapaça alta e larga, arredondada lateralmente atrás dos olhos laterais posteriores, e a região cefálica levemente convexa. Nosferattus é proposto para incluir cinco espécies: a espécie-tipo Nosferattus discus sp. nov. e Nosferattus ciliatus sp. nov. do Maranhão, Nosferattus aegis sp. nov. do Tocantins, Nosferattus occultus sp. nov. do Maranhão e do Ceará, e Nosferattus palmatus sp. nov. de Sergipe. Capeta e Amatorculus são ambos monotípicos e são propostos para incluir Capeta tridens sp. nov., da Bahia, e Amatorculus stygius sp. nov., do Distrito Federal e de São Paulo, respectivamente.

PALAVRAS CHAVE. Amycoida, neotropical, Sitticinae, sistemática, taxonomia.

Despite recent advances in knowledge on the phylogeny of the family Salticidae, there are still many unresolved relationships among its genera and higher taxonomic ranks. Within the Amycoida (sensu MAdDison \& Hedin 2003), a single lineage lost the teeth of the retromargin of the chelicerae (GaLiano 1987), composing the subfamily Sitticinae (sensu Petrunkevitch 1928). Although this group had its subfamily rank rejected without argumentation by GALIANO (1987), the term "sitticines" has still been used (MADDISON 1988, 1996) to refer to these spiders, and MAdDison \& Hedin (2003) showed by molecular analysis that the sitticine genera they sampled (Jollas Simon, 1901 and Sitticus Simon, 1901) grouped together.

With a single invasion into the Old World (the Sitticus/ Attulus lineage), the sitticine group has flourished in the Neotropical Region (MADDISON \& HEDIN 2003), where it's now revealing a larger diversity than previously thought, as foreseen by Galiano (1987). In addition to Sitticus, Jollas, Semiopyla Simon, 1901, Pseudattulus Caporiacco, 1947 and Aillutticus Galiano, 1987, the genera Nosferattus gen. nov., Capeta gen. nov. and Amatorculus gen. nov. are described in this paper from the Neotropical Region. These three genera are presumably related to
Aillutticus, with which they share a high, broad carapace, rounded laterally behind the PLE, and the dorsal surface of the cephalic region slightly convex (GALIANo 1987: figs 1,2). On the other hand, genital morphology is quite different from that of Aillutticus, which supports the proposal of new genera.

Although no observation has been made on the natural history of these new groups, GaLiano (1987) reported the habits of the species of Aillutticus, sitting on small rocks or gravel. All species here described were collected in pitfall traps, suggesting that they live on the ground, as observed by GALIANO (1987) for the species of Aillutticus.

\section{MATERIAL AND METHODS}

The material examined is deposited in the collections of the following institutions: Instituto Butantan (IBSP, A. D. Brescovit); Museu de Zoologia da Universidade de São Paulo (MZSP, R. Pinto da Rocha); Universidade Federal da Bahia (UFBA, T.K. Brazil).

The measurements are given in millimeters. Leg spinulation follows Galiano (1987). The abbreviations used throughout the text are: (RTA) retrolateral tibial apophysis, (AME) an- 
terior median eyes, (ALE) anterior lateral eyes, (PLE) posterior lateral eyes, (d) dorsal, (p) prolateral, (r) retrolateral, (v) ventral, (pr) proximal, (di) distal.

\section{Nosferattus gen. nov.}

Type species: Nosferattus discus sp. nov.

Etymology. The generic name is an elision of the Romanian mythical "Nosferatu" and the common ending for salticid genera "-attus". The grammatical gender is masculine.

Diagnosis. Males of Nosferattus can be distinguished from the remaining sitticine genera by the very flattened male palp, with a long embolus that curls between the tegulum and the edge of the cymbium (Figs 2, 6, 10, 15, 17). Females can be distinguished by the very long and coiled copulation ducts, seen through the translucent integument of the epigynal plate (Figs 4, 8, 13, 19).

Description. Small spiders (males 2.92-5.50 long, females 3.15-5.40 long), carapace high, broad, rounded laterally behind the PLE (Fig. 1), dorsal surface of the cephalic region slightly convex. Chelicerae small, parallel (except in Nosferattus ciliatus sp. nov., divergent), with 4-6 teeth on promargin, no conspicuous retromargin or any other modifications (except in males of Nosferattus occultus sp. nov., see figure 12). Endites rectangular, with no conspicuous projection. Cymbium very large when compared to body size (Fig. 1), dorsally covered with dense white scales. A fringe of small hairs on the ventral edge of the cymbium holds the curling embolus (Figs 2, 6, 10, 15, 17). Embolus thin, filiform, very long, with 1.25 to 3.5 turns around the tegulum. RTA with spurs, which can be free in alveoli (Figs 11, 16, 18) or fused (Figs 3, 7), fitting in a dorsal retroproximal depression of the cymbium. Spinulation (variations in parentheses). Male: femur I d1-1-1, p1di, r1di, II d1-11, p1di, r2di, III, IV d1-1-1, p2di, r2di; patella I, II, III, IV p1, r1; tibia I, II d1pr, v1r-1r-2, p1-1-1, r1-1-1, III, IV d1pr, v1p-0-2, p1-1-1, r1-1-1; metatarsus I, II v2-2, p1-1, r1-1, III d2-2, v2-2, p1-1, r1-1, IV d1-2, v1p-2, p1-1, r1-1. Female: femur I, II d1-11, p1di, r1di, III d1-1-1, p2di (p1di), r1di, IV d1-1-1, p2di, r2di; patella I, II 0, III, IV p1, r1; tibia I v1r-1r-2, p1-1-1, II v1r-1r-2, p1-1, III d1, v1p-1p, p1-1-1, r1-1-1, IV d1, v1p-0-2, p1-1-1, r11-1; metatarsus I, II v2-2, III v2di, p2-2, r2-2, IV v1pdi, p1-1-2, r1-1-2. Abdomen covered dorsally by a smooth oval scutum in males (except in Nosferattus occultus sp. nov.). Epigynal plate with a pair of semicircular small openings posteriorly (Figs 4 , $8,19)$ or with an atrium in the middle, formed by the fused epigynal openings (Fig. 13). Internally with very long and coiled copulation ducts, running freely around the spermathecae (Figs $5,9,20$ ) or organized, forming concentric spirals around a central duct (Fig. 14).

Comments. Nosferattus has a twisted cymbium, which probably evolved to support the long curling embolus. This pattern evolved several times within the family Salticidae and can also be seen, for example, in species of the terebratus group of Sitticus (Prószynski 1968: fig. 4) and in species of Maevia Simon,
1885 (BARNes 1955: fig. 7), which is in the Marpissinae.

Distribution. Known only from North/Northeastern Brazil (Maranhão, Ceará, Tocantins and Sergipe).

\section{Nosferattus discus sp. nov. Figs 1-5}

Types. Male holotype from Parque Nacional dos Lençóis Maranhenses ( $2^{\circ} 44^{\prime} 49^{\prime \prime}$ S, 42 49'39"W), Barreirinhas, Maranhão, Brazil, 12-18.X.2001, Equipe Biota leg. (IBSP 43784); allotype (IBSP 43786) and two male and two female paratypes with the same data as holotype (IBSP 43782, 43790; MZSP 23698, 23699).

Etymology. The specific name is a Latin noun that means "disc" and refers to the shape of the cymbium.

Diagnosis. Specimens of Nosferattus discus sp. nov. resemble those of $N$. aegis sp. nov. by the reduced RTA spurs, but differ by the retrolateral edge of the cymbium, which is closer to the edge of the tegulum in the males of $N$. discus (Fig. 2). Females can be distinguished from $N$. aegis by the dark brown abdomen in dorsal view and by the narrower posterior border of the epigynal openings (Fig. 4).

Description. Male (Fig. 1). Total length: 3.85. Carapace brown, 1.85 long, 1.40 wide, 1.00 high. Ocular quadrangle 0.80 long. Anterior eye row 1.25 wide and posterior 1.12 wide. Cephalic region black. Two light brown stripes extending from the PLE to the posterior edge of the carapace. Carapace laterally covered with dense white hairs. Chelicerae yellow, variegated with brown, with 5 teeth on promargin. Palpi brown, tibia and cymbium densely covered with white hairs. Legs yellow, with brown spots. Length of patella + tibia: I 1.10, II 1.00, III 0.95, IV 1.80. Sternum, labium and endites light brown. Abdomen pale cream, laterally and ventrally variegated with brown and covered by a dark brown dorsal scutum. Anterior spinnerets yellow, posterior brown.

Female. Total length: 4.35. Carapace brown, 1.95 long, 1.50 wide, 1.00 high. Ocular quadrangle 0.87 long. Anterior eye row 1.30 wide and posterior 1.25 wide. Carapace totally covered with white and brown hairs. Chelicerae yellow, with 4 teeth on promargin, palpi yellow. Legs yellow, with brown rings. Length of patella + tibia: I 1.05, II 0.95, III 0.95, IV 1.95. Sternum, labium and endites yellow. Abdomen brown, dorsally covered with brown hairs, laterally variegated, ventrally pale cream. Epigynum with a pair of lateral digitiform glands flowing at the beginning of the copulation ducts (Figs 4, 5). Spinnerets yellow.

Variation. Ten males: total length: 3.55-4.15; carapace length: 1.75-1.95. Ten females: total length: 3.80-5.00; carapace length: 1.75-2.05.

Other material examined. BrazIL, Maranhão: Barreirinhas (Parque Nacional dos Lençóis Maranhenses), 30 males, 15 females, 12-18.X.2001, Equipe Biota leg. (IBSP 43775-43781, 43783, 43785, 43787-43789, 43791-43800).

Distribution. Known only from the State of Maranhão, Brazil.

Revista Brasileira de Zoologia 22 (3): 687-695, setembro 2005 

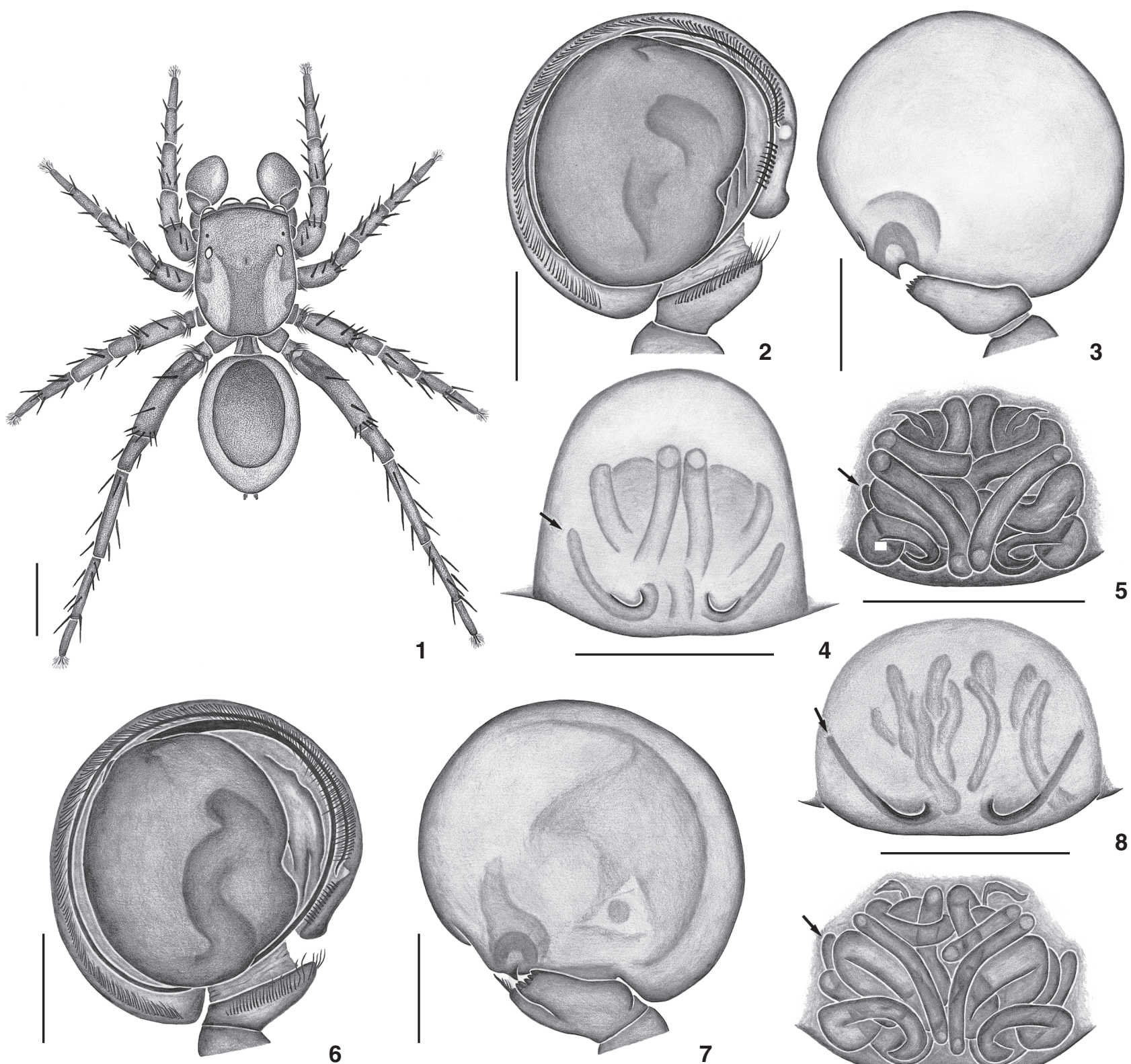

Figures. 1-9. (1-5) Nosferattus discus sp. nov.: (1) dorsal habitus of the male; (2) male palp, ventral view; (3) dorsal view; (4) epigynum, ventral view; (5) dorsal view; (6-9) Nosferattus aegis sp. nov.: (6) male palp, ventral view; (7) dorsal view; (8) epigynum, ventral view; (9) dorsal view. Arrows: digitiform gland. Scale lines: (1) $1 \mathrm{~mm}$; (2-9) $0.25 \mathrm{~mm}$.

\section{Nosferattus aegis sp. nov.}

Figs 6-9

Types. Male holotype from Palmas $\left(10^{\circ} 12^{\prime} 10,6^{\prime \prime}\right.$, $\left.48^{\circ} 21^{\prime} 64^{\prime \prime} \mathrm{W}\right)$, Tocantins, Brazil, 2-9.VII.2002, I. Knysak \& R. Martins leg. (IBSP 43307); allotype from Porto Nacional, Tocantins, Brazil, 16.VIII.2001, F.B. Rielli leg. (IBSP 43359) and two male and two female paratypes with the same data as holotype (IBSP 43315, 43323; MZSP 23700, 23701).

Etymology. The specific name is a Latin noun that means "shield" and refers to the shape of the cymbium.

Diagnosis. Nosferattus aegis sp. nov. is similar to N. discus by the reduced RTA spurs, but differs by the retrolateral edge of the cymbium, which is farther away from the edge of the 
tegulum in the males of $N$. aegis, exposing a larger area of the alveolus of the cymbium of the male palp on the retrolateral side (Fig. 6). Females can be distinguished from N. discus by the orange abdomen in dorsal view and by the wider posterior border of the epigynal openings (Fig. 8).

Description. Male. Total length: 3.85. Carapace variegated with dark yellow and light brown, 2.00 long, 1.45 wide, 1.05 high, with dark edges. Ocular quadrangle 0.82 long. Anterior eye row 1.35 wide and posterior 1.25 wide. Cephalic region dark brown, with a wide dark brown stripe extending from between the PLE to the posterior edge of the carapace. Carapace laterally covered with white hairs, cephalic region covered with short golden hairs close to the AME and the ALE. Long brown hairs among the eyes, mainly close to the AME and the ALE. Clypeus densely covered with white hairs. Chelicerae small, yellow, with a longitudinal brown stripe and 5 teeth on promargin. Palpi dark yellow, ventrally light brown, cymbium light brown, densely covered with white hairs dorsally. Legs yellow, femora with light brown rings. Length of patella + tibia: I 1.25, II 1.15, III 1.10, IV 2.00. Sternum, labium and endites yellow. Abdomen dorsally covered by a dark scutum, laterally and ventrally greenish-gray and densely covered with white and golden hairs. Anterior spinnerets yellow and posterior dark brown.

Female. Total length: 4.15. Carapace light brown, slightly variegated, 1.95 long, 1.60 wide, 1.12 high. Ocular quadrangle 0.92 long. Anterior eye row 1.30 wide and posterior 1.30 wide. A longitudinal dark brown stripe along the dorsal middle of the carapace. Carapace with dark brown edges. Cephalic region dark brown covered with short light brown hairs. Some long dark hairs around the AME. Clypeus densely covered with white and brown hairs. Chelicerae with 5 teeth on promargin. Palpi yellow, legs yellow with brown rings close to the joints. Length of patella + tibia: I 1.20, II 1.10, III 1.10, IV 2.17. Sternum, labium and endites yellow. Abdomen brown, densely covered with orange and brown hairs, with a dorsal glabrous area, ventrally pale cream. Epigynum with a pair of lateral digitiform glands flowing at the beginning of the copulation ducts (Figs 8, 9). Anterior spinnerets yellow, posterior brown.

Variation. Ten males: total length: 3.70-4.15; carapace length: 1.85-2.15. Ten females: total length: 3.70-5.40; carapace length: 1.95-2.15.

Other material examined. BraziL, Tocantins: Palmas $\left(10^{\circ}\right.$ $12^{\prime} 10,6^{\prime \prime}$ S, 48 $\left.21^{\prime} 64^{\prime \prime} \mathrm{W}\right), 13$ males, 3 females, 2-9.VII.2002, I. Knysak \& R. Martins leg. (IBSP 43308-43314, 43316-43322, 43324); Lageado, 2 males, 4.VI.2001, F.B. Rielli leg. (IBSP 43325, 43329); Brejinho do Nazaré, 1 male, 1 female, 13.VII.2001, F.B. Rielli leg. (IBSP 43326); Lageado, 2 females, F.B. Rielli leg. (IBSP 43327, 43328); Palmas, 1 male, 1 female, VIII.2001, F.B. Rielli leg. (IBSP 43330, 43331); Palmas, 1 female, F.B. Rielli leg. (IBSP 43332); Palmas, 1 male, 2 females, 12.VI.2001, F.B. Rielli leg. (IBSP 4333343335); Porto Nacional $\left(10^{\circ} 42^{\prime} 82,7^{\prime \prime} \mathrm{S}, 48^{\circ} 25^{\prime} 12^{\prime \prime} \mathrm{W}\right), 11$ males, 18 females, 14-23.II.2003, I. Knysak \& R. Martins leg. (IBSP 4333643346); Palmas, Taquaralto, Jardim Taquari $\left(10^{\circ} 20^{\prime} 53,2^{\prime \prime} \mathrm{S}\right.$, $48^{\circ} 20^{\prime} 98,1^{\prime \prime}$ ) $), 4$ males, 4-10.XI.2002, I. Knysak \& R. Martins leg. (IBSP 43347-43350); Palmas, 2 males, 20-24.XI.2000, I. Knysak \& R. Martins leg. (IBSP 43351, 43352); Porto Nacional, 8 males, 4 females, 16.VIII.2001, F.B. Rielli leg. (IBSP 43353-43358, 4376943773); Palmas, 32 males, 3 females, 18-23.III.2001, R. Martins \& G. Puorto leg. (IBSP 43745-43768).

Distribution. Known only from the State of Tocantins, Brazil.

\section{Nosferattus occultus sp. nov. Figs 10-14}

Types. Male holotype from Parque Nacional dos Lençóis Maranhenses ( $2^{\circ} 44^{\prime} 49^{\prime \prime}$, 42 49'39"W), Barreirinhas, Maranhão, Brazil, 12-18.X.2001, Equipe Biota leg. (IBSP 43809); allotype (IBSP 43812) and two male and two female paratypes with the same data as holotype (IBSP 43813, 43810; MZSP 23705).

Etymology. The specific name is a Latin adjective that means "hidden" and refers to the embolus, hidden behind the edge of the tegulum.

Diagnosis. Males of Nosferattus occultus sp. nov. can be easily distinguished from the remaining species of the genus by the length of the embolus, coiled 3.5 times around the tegulum, by the uniformly circular large tegulum and by the RTA with two strong spurs (Figs 10, 11). Females can be distinguished by the narrow atrium on the epigynal plate and the uniformly coiled copulation ducts, forming concentric spirals around a central duct (Figs 13, 14).

Description. Male. Total length: 4.60. Carapace yellow, 2.15 long, 1.70 wide, 1.15 high. Ocular quadrangle 1.10 long. Anterior eye row 1.50 wide and posterior 1.45 wide. Cephalic region black, with a wide stripe of black hairs extending from between the PLE through the carapace and the dorsal surface of the abdomen, reaching the anal tubercle. Carapace laterally covered with light hairs. Chelicerae yellow, excavated on anterior surface, with a fringe of modified hairs on the external edge of the concavity (Fig. 12) and 5 teeth on promargin. Embolus very long (3.5 turns), curling in a groove at the edge of the tegulum. Longitudinal brown stripes proventrally on legs I, II and III. Length of patella + tibia: I 1.35, II 1.15, III 1.15, IV 2.10. Sternum, labium and endites yellow. Abdomen pale, covered with light brown hairs and white hairs laterally. No conspicuous dorsal scutum.

Female. Total length: 4.80. Carapace light brown, 2.25 long, 1.75 wide, 1.25 high. Ocular quadrangle 0.90 long. Anterior eye row 1.50 wide and posterior 1.45 wide. Carapace densely covered with brown hairs. Cephalic region dark. Small tufts of white hairs between the AME and the ALE. Chelicerae unmodified, with 5 teeth on promargin. Legs with dark rings. Length of patella + tibia: I 1.20, II 1.15, III 1.20, IV 2.20. Sternum, labium and endites yellow. Abdomen covered with brown and orange hairs, ventrally pale cream.

Variation. Seven males: total length: 4.35-5.70; carapace length: 2.15-2.40. Six females: total length: 4.30-5.15; carapace length: $2.10-2.30$. 

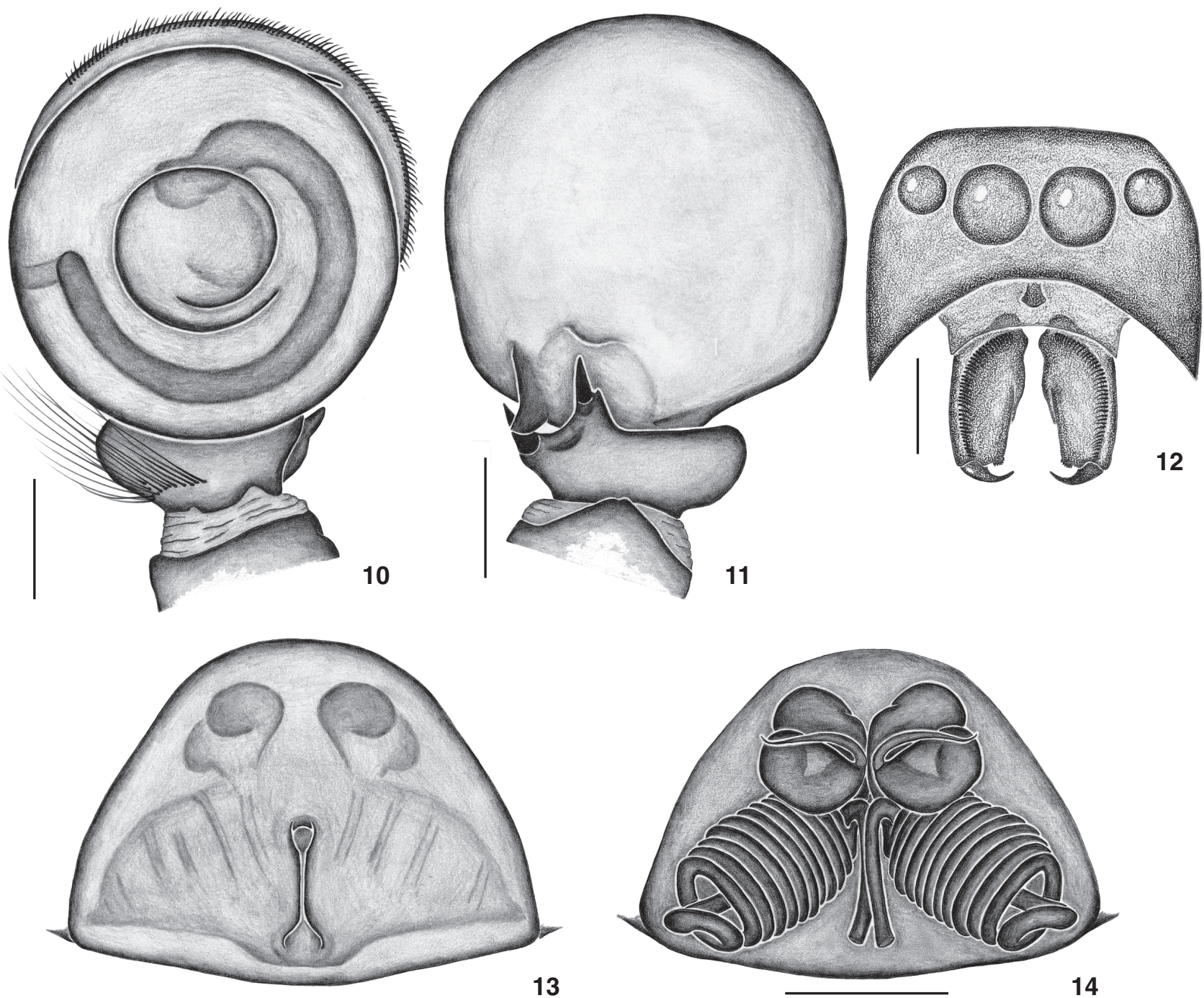

Figures 10-14. Nosferattus occultus sp. nov.: (10) male palp, ventral view; (11) dorsal view; (12) male chelicerae; (13) epigynum, ventral view; (14) dorsal view. Scale lines: (10-11) $0.25 \mathrm{~mm}$; (12) $0.5 \mathrm{~mm}$; (13-14) $0.25 \mathrm{~mm}$.

Other material examined. BraziL, Maranhão: Barreirinhas (Parque Nacional dos Lençóis Maranhenses), 3 males, 3 females, 12-18.X.2001, Equipe Biota leg. (IBSP 43809, 43814-43816); Ceará: Crateús, Serra das Almas, 1 male, IV.2003, M. Carvalho leg. (IBSP 43817).

Distribution. Known from the States of Maranhão and Ceará, Brazil.

\section{Nosferattus ciliatus sp. nov. Figs 15,16}

Types. Male holotype from Parque Nacional dos Lençóis

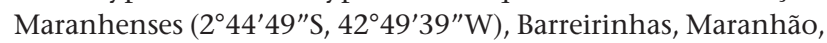
Brazil, 12-18.X.2001, Equipe Biota leg. (IBSP 43801); two male paratypes with the same data as holotype (IBSP 43803; MZSP
23702)

Etymology. The specific name is a Latin adjective that means "ciliated" and refers to the ventral edge of the cymbium.

Diagnosis. The males of Nosferattus ciliatus sp. nov. can be distinguished from the remaining species by the subdistal prolateral origin of the embolus, and by the closely set RTA spurs (Figs 15, 16).

Description. Male. Total length: 3.15. Carapace yellow, 1.55 long, 1.10 wide, 0.80 high. Ocular quadrangle 0.75 long. Anterior eye row 1.02 wide and posterior 0.97 wide. Cephalic region dark brown. Wide stripe extending from the cephalic region to the posterior edge of the carapace. Narrow stripes of white hairs extending from the posterior edge of the carapace to the anterior edge, touching the inner side of the PLE. Chelicerae uncom- 
monly divergent, yellow, brown proximally, with 5 teeth on promargin. Coloration and hair pattern of palpi as in $N$. discus. Legs yellow with sparse brown spots. Length of patella + tibia: I 0.90, II 0.75, III 0.80, IV 1.35. Sternum, labium and endites yellow. Abdomen pale cream with a pair of longitudinal brown stripes dorsally and a narrow median stripe of white hairs. Anterior spinnerets yellow, posterior brown.

Female. Unknown.

Variation. Four males: total length: 3.00-3.15; carapace length: 1.50-1.60.

Other material examined. BRAZIL, Maranhão: Barreirinhas (Parque Nacional dos Lençóis Maranhenses), 1 male, 1218.X.2001, Equipe Biota leg. (IBSP 43802).

Distribution. Known only from the State of Maranhão, Brazil.

\section{Nosferattus palmatus sp. nov. Figs 17-20}

Types. Male holotype from Usina Hidrelétrica de Xingó, Canindé do São Francisco, Sergipe, Brazil, 31.X.2000, L. Ianuzzi leg. (IBSP 43806); allotype (IBSP 43807) and two male and two female paratypes with the same data as holotype (IBSP 43804, 43805; MZSP 23703, 23704).

Etymology. The specific name is a Latin adjective that means "webbed" and refers to the webbed palpal tibia in dorsal view.

Diagnosis. The males of Nosferattus palmatus sp. nov. can be distinguished from the remaining species by the reduced tegulum, the proximal prolateral origin of the embolus and by the free RTA spurs (Fig. 18). The females can be distinguished from others by the openings close together posteromedially on the epigynal plate (Fig. 19).

Description. Male. Total length: 2.92. Carapace brown, 1.60 long, 1.25 wide, 0.82 high, with brown lateral edges. Ocular quadrangle 0.77 long. Anterior eye row 1.12 wide and posterior 1.10 wide. Cephalic region dark. Carapace covered with white hairs. Chelicerae yellow, with 5 teeth on promargin. Palpi yellow. Legs yellow with brown spots. Length of patella + tibia: I 0.87, II 0.82, III 0.77, IV 1.31. Sternum, labium and endites yellow. Abdomen cream, with a large smooth brown scutum covering the entire dorsal surface, laterally and ventrally pale cream, with white hairs.

Female. Total length: 3.55. Carapace brown, 1.67 long, 1.22 wide, 0.80 high. Ocular quadrangle 0.70 long. Anterior eye row 1.10 wide and posterior 1.07 wide. Legs yellow with brown rings. Length of patella + tibia: I 0.80, II 0.75, III 0.77, IV 1.35. Sternum, labium and endites yellow. Abdomen brown, laterally variegated, ventrally pale cream. Spinnerets yellow.

Variation. Three males: total length: 2.92-3.05; carapace length: 1.55-1.60. Four females: total length: 3.15-4.15; carapace length: $1.67-1.75$.

Other material examined. BraziL, Sergipe: Canindé do São Francisco (Usina Hidrelétrica de Xingó), 1 female, 31.X.2000, L. Ianuzzi leg. (IBSP 43808).

Distribution. Known only from the State of Sergipe, Brazil.

\section{Capeta gen. nov.}

Type species: Capeta tridens sp. nov.

Etymology. The generic name is a Brazilian word for "Devil". The grammatical gender is masculine.

Diagnosis. Males of Capeta gen. nov. can be distinguished from the remaining sitticine genera by the elongated cymbium, the long and straight embolus, with a basal projection, and the long RTA (Figs 21, 22). Females can be distinguished by the epigynal plate with a posterior tongue-like projection and a large median atrium, and by the long spermathecae (Figs 23, 24).

Description. Small spiders (males 3.70-4.65 long, females 3.70-4.80 long), carapace as in Nosferattus (Fig. 1). Chelicerae as in Nosferattus, with 4-5 teeth on promargin. Endites as in Nosferattus. Cymbium elongated distally, a long and straight embolus with a hook-like tip and a basal projection. Tegulum small, cup shaped. Palpal tibia with very long RTA, sclerotized and acute, and a ventral tibial projection (Figs 21, 22). Spinulation (variations in parentheses). Male: femur I d1-1-1, p1di, r1di, II d1-1-1, p2di, r2di, III d0-1-1, p2di, r2di, IV d1-0-1, p2di, r2di; patella I p1 (p0), II p1, III, IV p1, r1; tibia I, II v2-2-2, p1-1, III, IV d1pr, v1p-0-2, p1-1-1, r1-1-1; metatarsus I, II v2-2, III v1r-2, p22, r2-2, IV d1rpr-0-2, v2di, p1-1-1. Female: femur I d1-1-1, p1di, II d1-1-1, p2di, r2di, III d1-1-1, p2di, r2di, IV d1-0-1, p2di, r2di; patella I, II 0, III, IV p1, r1; tibia I, II v2-1r-2, p1-1-1, III, IV d1pr, v1p-0-2, p1-1-1, r1-1-1 (r1-1); metatarsus I, II v2-2, III v1r-2, p22, r2-2, IV v1pdi, p1-1-2, r2-1-2. Epigynal plate with a single, large transversal atrium, with a wide projection on the posterior edge and longitudinally elongated and coiled copulation ducts and elongated spermathecae (Figs 23, 24).

Distribution. Known only from the State of Bahia, Brazil.

\section{Capeta tridens sp. nov.}

Figs $21-24$

Types. Male holotype from Parque do Abaeté, Salvador, Bahia, Brazil, IV.2001, R. Smania-Marques leg. (IBSP 43824); allotype (IBSP 43825) and two male and two female paratypes with the same data as holotype (IBSP 44447, 44444; MZSP 23708, 23709).

Etymology. The specific name is a Latin noun that means "trident" and refers to the three projections in the male palp seen in ventral view (the embolus, its basal projection and the RTA).

Diagnosis. See generic diagnosis.

Description. Male. Total length: 4.65. Carapace yellow, laterally variegated with brown, 2.40 long, 1.80 wide, 1.27 high. Ocular quadrangle 1.02 long. Anterior eye row 1.57 wide and posterior 1.62 wide. Black rings around eyes. Median dorsal dark brown stripe on thoracic region. Chelicerae yellow, brown distally, with 5 teeth on promargin. Palpi and legs yellow, femora IV prolaterally with brown median stain. Small brown spots on legs. Length of patella + tibia: I 1.60, II 1.25, III 1.15, IV 2.55. Sternum, labium and endites yellow. Abdomen elon- 

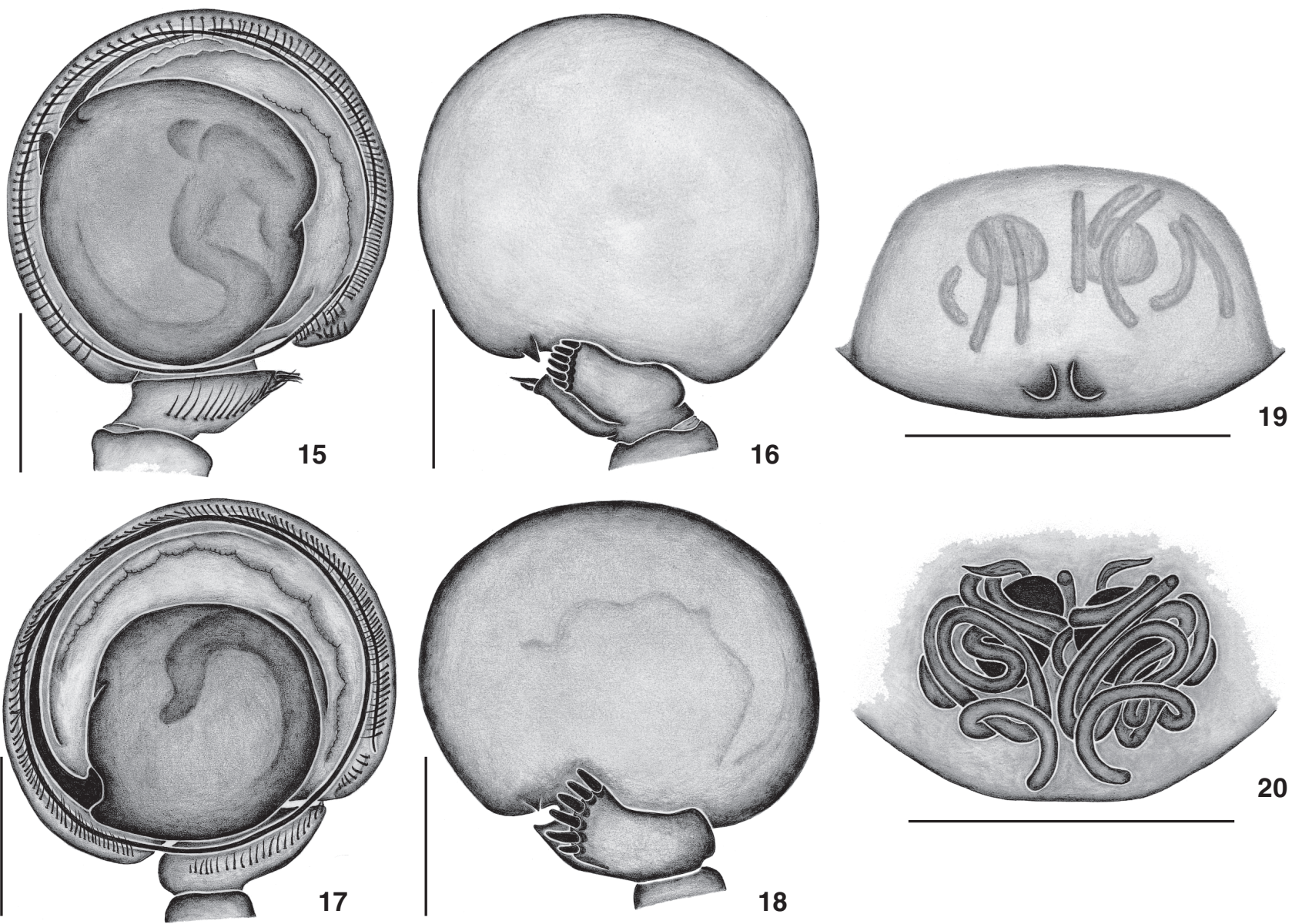

Figures 15-20. (15-16) Nosferattus ciliatus sp. nov., male palp: (15) ventral view; (16) dorsal view; (17-20) Nosferattus palmatus sp. nov.: (17) male palp, ventral view; (18) dorsal view; (19) epigynum, ventral view; (20) dorsal view. Scale lines: $0.25 \mathrm{~mm}$.

gated, pale cream, laterally and ventrally variegated. Anterior half more sclerotized dorsally, but without a well delimited scutum. A pair of brown spots on anterior half and three brown chevrons on posterior dorsal half. Spinnerets brown.

Female. Total length: 4.80. Carapace variegated with light brown, 2.05 long, 1.60 wide, 1.00 high, with a pair of dark longitudinal stripes extending from the cephalic region to the posterior edge. Ocular quadrangle 0.82 long. Anterior eye row 1.35 wide and posterior 1.42 wide. Chelicerae with 4 teeth on promargin. Length of patella + tibia: I 1.15, II 1.00, III 0.95, IV 2.02. Sternum, labium and endites yellow. Abdomen light brown, variegated, with the cardiac impression lighter, pale cream ventrally.

Variation. Four males: total length: 3.70-4.65; carapace length: 2.20-2.50. Ten females: total length: 3.70-4.80; carapace length: 1.90-2.10.

Other material examined. BrazIL, Bahia: Salvador (Parque do Abaeté), 1 male, 14 females, IV.2001, R. Smania-Marques leg. (IBSP 44441-44443, 44445, 44448-44453, UFBA)

Distribution. Known only from the State of Bahia, Brazil.

\section{Amatorculus gen. nov.}

Type species: Amatorculus stygius sp. nov.

Etymology. The generic name is a Latin noun that means "small friend". The grammatical gender is masculine.

Diagnosis. Males of Amatorculus gen. nov. can be distinguished from the remaining sitticine genera by the combination of a very short embolus, a spherical tegulum and a bifid RTA (Figs 25, 26). Females can be distinguished by the circular median opening on the epigynal plate (Fig. 27).

Description. Small spiders (males 3.85-4.50 long, females 3.35-4.47 long), carapace, chelicerae and endites as in Nosferattus. Tegulum oval, embolus very short, a ventral tibial projection, RTA bifid, with the dorsal branch elongated and acute. A tuft of long hairs on the dorsal tibia. Spinulation (variations 


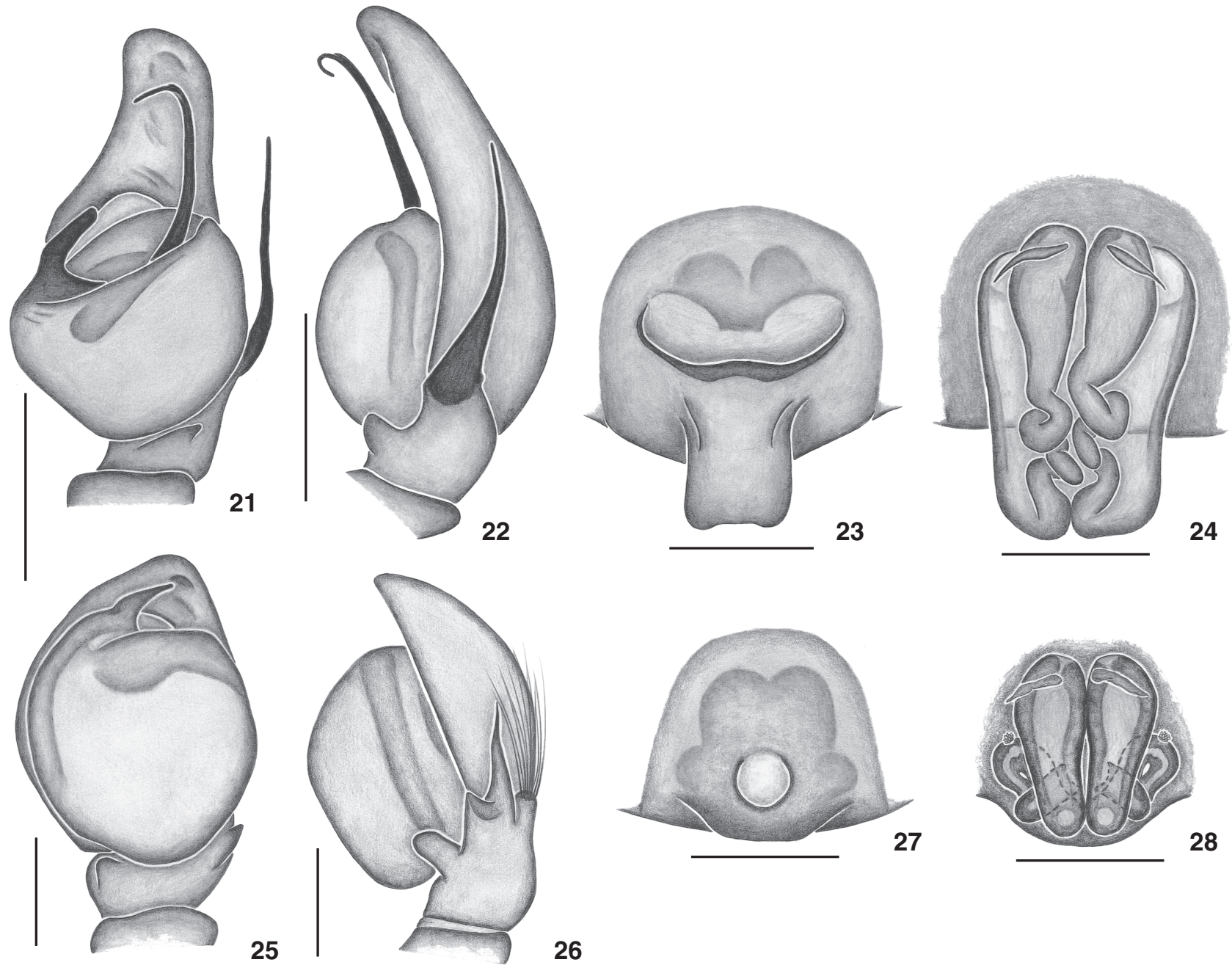

Figures 21-28. (21-24) Capeta tridens sp. nov.: (21) male palp, ventral view; (22) retrolateral view; (23) epigynum, ventral view; (24) dorsal view; (25-28) Amatorculus stygius sp. nov.: (25) male palp, ventral view; (26) retrolateral view; (27) epigynum, ventral view; (28) dorsal view. Scale lines: $0.25 \mathrm{~mm}$.

in parentheses). Male: femur I d1-1-1, p1di, r1di, II d1-1-1, p2di, r1di, III, IV d1-1-1, p2di, r2di (r1di); patella I, II p1, III, IV p1, r1; tibia I, II v1r-1r-2, p1-1-1, III, IV d1, v1p-0-2, p1-1-1, r1-1-1 (r1-1, r1); metatarsus I, II v2-2, III v2di, p2-2, r2-2, IV v1pdi, p1-1-2, r2-1-2. Female: femur I d1-1-1, p1di, r1di (r0), II, III, IV d1-1-1, p2di (p1di), r2di; patella I, II 0, III, IV p1, r1; tibia I, II v2-1r-2, p1-1-1, III d1, v1p-0-1p, p1-1-1, r1-1, IV d1, v1p-0-2, p1-1-1, r1-1-1; metatarsus I, II v2-2, III v2di, p2-2, r2-2, IV v1pdi, p1-1-2 (p0-1-2), r2-1-2 (r0-1-2). Abdomen covered by a dorsal scutum. Epigynal plate with a circular opening and internally with elongated spermathecae, long and sinuous copulation ducts and apical fertilization ducts (Figs 27, 28).

Distribution. Known from Distrito Federal and the State of São Paulo, Brazil.

\section{Amatorculus stygius sp. nov.}

Figs 25-28

Types. Male holotype from Reserva Ecológica do Instituto Brasileiro de Geografia e Estatística, Brasília, Distrito Federal, Brazil, III-IV.2000, D. Briani leg. (IBSP 28391); allotype (IBSP 43822) and two male and two female paratypes from Estação Ecológica de Itirapina, Itirapina, São Paulo, Brazil, 2001-2002, C.R. Bertim leg. (IBSP 43818, 43823; MZSP 23706, 23707).

Etymology. The specific name is a Latin adjective that means "from hell".

Diagnosis. See generic diagnosis.

Description. Male. Total length: 4.50. Carapace dark yel- 
low, 1.97 long, 1.60 wide, 1.05 high. Ocular quadrangle 0.95 long. Anterior eye row 1.30 wide and posterior 1.37 wide. Black rings around eyes, wide brown stripe extending from the fovea to the posterior edge of the carapace, dark stripes extending from the PLE almost to the posterior edge of the carapace. Carapace with brown edges. Chelicerae brown, with variegated prolateral side and 5 teeth on promargin. Palpi dark brown. Legs light yellow, with a small proventral dark brown spot on the base of femur IV. Small dark brown spots on prolateral coxae. Length of patella + tibia: I 1.20, II 1.05, III 0.95, IV 2.00. Sternum dark yellow with a dark brown Ushaped stain. Labium and endites yellow. Abdomen pale cream with a dorsal light brown scutum on the anterior half. Spinnerets brown.

Female. Total length: 4.47. Carapace dark yellow, 1.90 long, 1.47 wide, 0.95 high. Ocular quadrangle 0.85 long. Anterior eye row 1.30 wide and posterior 1.27 wide. Carapace covered with light brown hairs, black rings around eyes, two light brown stripes from each side of fovea and light stripes extending from the PLE almost to the posterior edge of the carapace. Chelicerae, palpi and legs light yellow, with no spots. Length of patella + tibia: I 1.90, II 0.95, III 1.00, IV 1.10. Sternum, labium and endites light yellow. Abdomen light yellow, dorsally with irregular light brown spots and inconspicuous chevrons on the posterior third. Abdomen laterally and ventrally slightly variegated with light brown, all covered with light brown hairs. Spinnerets light yellow.

Variation. Six males: total length: 3.85-4.50; carapace length: 1.95-2.15. Three females: total length: 3.35-4.47; carapace length: 1.70-1.90.

Other material examined. BRAZIL, São Paulo: Itirapina (Estação Ecológica de Itirapina), 3 males, 2001-2002, C.R. Bertim leg. (IBSP 43819-43821).

Distribution. Known from Distrito Federal and the State of São Paulo, Brazil.

\section{ACKNOWLEDGMENTS}

We wish to thank CNPq (Conselho Nacional de Desenvolvimento Científico e Tecnológico) and FAPESP (Fundação de Amparo à Pesquisa do Estado de São Paulo, 99/05446-8 and 03/ 02556-4) for the financial support. We also thank G.B. Edwards, Cristina A. Rheims, Arno A. Lise and Erica H. Buckup for suggestions on the manuscript. This study is part of the BIOTA/FAPESP - the Biodiversity Virtual Institute Program (www.biotasp.org.br).

\section{REFERENCES}

BARNES, R.D. 1955. North American jumping spiders of the genus Maevia. American Museum Novitates, New York, 1746: 113.

Galiano, M.H. 1987. Description of Aillutticus, new genus (Araneae, Salticidae). Bulletin of the British Arachnology Society, Dorset, 7 (5): 157-164.

MadDison, W.P. 1988. A revision of jumping spider species groups formerly placed in the genus Metaphidippus, with a discussion of salticid phylogeny (Araneae). Available on World Wide Web at http://tolweb.org/tree?group = Sitticinae\& contgroup = Salticidae, accessed November 22 2004.

Maddison, W.P. 1996. Pelegrina Franganillo and other jumping spiders formerly placed in the genus Metaphidippus (Araneae: Salticidae). Bulletin of the Museum of Comparative Zoology, Cambridge, 154: 215-368.

Maddison, W.P. \& M.C. Hedin. 2003. Jumping spider phylogeny (Araneae: Salticidae). Invertebrate Systematics, Victoria, 17: 529-549.

Petrunkevitch, A. 1928. Systema Aranearum. Transactions of the Connecticut Academy of Arts and Sciences, New Haven, 29: 1-270.

Prószynski, J. 1968. Revision of the spider genus Sitticus Simon (Araneida, Salticidae) I. The terebratus group. Annales zoologici, Warszawa, 26: 391-407.

Received in 06.12.2004; accepted in 15.VIII.2005. 